\title{
The Effect of Extract of Getih-Getihan (Rivina humilis L.) on Armyworm (Spodoptera litura F.) Mortality
}

\author{
Dewi Nurhayati ${ }^{1)}$, Wachju Subchan ${ }^{1)}{ }^{凶}$, Jekti Prihatin ${ }^{1)}$ \\ ${ }^{1}$ Biology Education, Faculty of Teacher Training and Education, University of Jember \\ Email: wachju.fkip@unej.ac.id
}

\begin{abstract}
Armyworm (Spodoptera litura F.) is a leaf-eating pest causes the loss of crops from $85 \%$ until causing crop failure. Alternative pest control and to reduce the negative impact of synthetic pesticides include using botanical pesticide. Getih-getihan plant (Rivina humilis L.) is one of the plants having potency as a botanical pesticide. Based on the description, this study was conducted to determine LC50 value by using probit analysis and analysis of an extract of Rivina humilis L. leaves on the mortality of Spodoptera litura F. using ANOVA test. Rivina humilis L. leaves are extracted by using ethanol solvent to get active chemical to kill Spodoptera litura F.. TLC (Thin Layer Chromatography) result test of an extract of Rivina humilis L. are positively contain an alkaloid, flavonoid, tannin, and terpenoid. The method of the research uses CRD (Complete Random Design) with five times repetition. Concentration serial being tested are $0 \%, 0.5 \%, 1 \%, 1.5 \%, 2 \%$, and $2.5 \%$. The result of probit analysis is $1.42 \%$ of LC50 value and ANOVA test shows that extract of Rivina humilis L. leaves affects very significantly on the Spodoptera litura $\mathrm{F}$. mortality $(\mathrm{p}=0.000)$.
\end{abstract}

Keywords: Spodoptera litura $F$., Rivina humilis $L$., leaves extract.

\section{INTRODUCTION}

Armyworm (Spodoptera litura F.) is a pest that has a wide range of hosts plant, which is potentially becoming a pest in various types of food crops, vegetables, fruits, and plantations [1]. Several main crops attacked by this pest include tobacco, peanut, chilli, cabbage, sunflower, cotton, and taro [2]. The existence of armyworm in Indonesia can cause loss of yields up to $85 \%$, even cause crop failure if it is not controlled [3]. So far, farmers effort to control a pest is by using synthetic pesticides.

Synthetic pesticides are believed to be powerful for killing pests, but continuous use and non-accordance with recommended rules can have negative impacts. The negative impacts of synthetic pesticide use are, pests become immune (resistant), blasting of new pests (resurrection), the death of natural enemy population, environmental pollution through abandoned residue, and occurrence of poisoning in humans [4]. One of the negative impacts that have been proven in Jember is that the value of Resistance Factor (FR) of armyworm against synthetic pyrethroid (alpha metrin) reaches FR 45,5.
The value is much higher than the FR $\geq 5$ value which means that the controlled insect has been resistant to the pesticide. Other synthetic pesticides that are resistant to armyworm in Jember include fenvalerate, deltamethrin, and lihda cyhalothrin [5]. Poor control of pests raises resistance among them with botanical pesticides [6].

Botanical pesticides have a biodegradable nature that is relatively safe for humans, livestock, and does not pollute the environment, and can be used to reduce the use of synthetic pesticides [7]. Botanical pesticides are made by utilizing compounds or secondary metabolites toxic contained in the extraction of certain parts of the plant, such as leaves, fruits, seeds or roots to control certain plant pests and diseases [8]. In nature, there are many plants having active compounds such as phenol, alkaloids, flavonoids, terpenes, quinones, coumarins, and others acting as a defence against insect pests [9]. One of the plants that have the potential as a botanical pesticide is getih-getihan plant (Rivina humilis L.).

Getih-getihan plants (Rivina humilis L.) are often found in places such as open 
forests, gardens, fences [10], roadsides, rivers, and other shady spots [11]. This plant has aromatic and toxic on the leaves and roots, but has not been identified its toxic compounds [12]. Aromatic plants usually produce many compounds that can resist insects or act to alter insect feeding, growth and development, ecdysis (moulting), marital behaviour and oviposition [13]. The various active compounds contained in the gum can potentially be insecticides include alkaloids, flavonoids, resins, tannins [14], cardiac glycosides, quinones, terpenoids, coumarins, and steroids [15]. This plant has been tested to effectively control the pests of warehouses that are considered important in Indonesia namely the red beetle flour (Tribolium castaneum) [16]. The potency of getih-getihan plant in its leaves is extracted to be tested the effect of armyworm mortality.

The production of getih-getihan leaves extract was done by using $96 \%$ ethanol solvent. Ethanol is one of solvent besides water that has low cytotoxicity [17]. Ethanol has an activity that efficiently degrades the cell wall and universal because it has two sides composed of a polar $-\mathrm{OH}$ group and a $\mathrm{CH} 2 \mathrm{CH} 3$ group non-polar [18]. Various active compounds contained in getih-getihan leaves which are polar and non-polar can be dissolved in ethanol. Based on the description, this study was conducted to determine the value of LC50 and to analyze the effect of leaves extract of Rivina humilis L. on the mortality of Spodoptera litura F.

\section{RESEARCH METHOD \\ Types of research}

Type of research used is laboratory experimental research. The research was conducted by using Completely Randomized Design (CRD) and it used 5 replication.

\section{Tools and Materials}

The tools used in this research include knives, blenders, finely sieved, spoons, stirrers, erlenmeyer $1000 \mathrm{ml}$, funnel, analytical scales, filter paper, filter cloth, shaker, rotary evaporator, water bath, aluminum foil, spatula, beaker glass 1000 $\mathrm{ml}$, petri dish, bottle glass $1500 \mathrm{ml}$, tissue paper, rubber band, chiffon fabric, scissors, stationery, label paper, filter paper, brush no.1, spray bottle, digital camera, ruler, stop watch, thermohigro meters, lux meters, jam bottles, capillary pipes, water panels, and vortex.

The materials used in this research are armyworm (Spodoptera litura F.) instar III, getih-getihan leaves (Rivina humilis L.), 96\% ethanol, aquades, water, kale leaves, $\mathrm{HCl} 2 \mathrm{~N}, \mathrm{NaCl}$, ammonia, chloroform, methanol, TLC plates (Klesel gel F254), Dragendorf reagents, ethyl acetate, nhexane, butanol, acetic acid, $\mathrm{FeCl} 3$ reagents, sulfuric acid anisaldehyde reagents.

\section{Preparation Research Procedure}

The condition of bottles must be in a clean and dry when it is used as a place of experiment. The bottle is closed using a chiffon fabric and tied with a rubber band.

\section{Preservation of Armyworm (Spodoptera litura F.)}

Armyworm test animals (Spodoptera litura F.) were obtained from Indonesia Sweetener and Fiber Crop Research Institute or "BALITTAS" Malang at the time of the first instar armyworm. Then they were removed and kept in a mineral bottle covered with chiffon fabric. The armyworm is given the same feed that is Ipomoea aquatica leaves, at the time of preservation until the treatment is done. Determination of armyworm in a certain phase can be done by observing the worm to experience the turn of the 2nd (molting) or by observing the characteristics of the worm body based on the literature. The preservation of armyworm (Spodoptera litura F.) is kept 
being clean by cleaning up the dirt every day and maintaining the place to be dry.

\section{Production of Extract of Getih-getihan (Rivina humilis L.)}

Getih-getihan leaves were obtained in the yard near the river of Sempolan Village, Silo district, Jember Regency. The leaves were taken in dark green colour from the fourth sitting leaves to the tenth sitting leaves. The leaves chosen were collected as much as $1000 \mathrm{mg}$ or $1 \mathrm{~kg}$ and washed with flowing water. Getih-getihan leaves then were dried in the shade (not exposed to direct sunlight). Dried getih-getihan leaves were blended and sieved to obtain a fine powder for \pm 150 grams. The next process of getih-getihan leaves powder was immersed in $96 \%$ ethanol with $96 \%$ ethanol (solvent) and 5: 1 leaf-dusted powder. Soaking or maceration process was done for $2 \times 24$ hours (2 days) and stirring every 24 hours. The duration of the immersion process was carried out in accordance with the research which has been done that the production of maceration extract method with ethanol solvent took $2 \times 24$ hours to produce the optimum extract [19]. The immersion solution was filtered with a funnel that has been dialled using filter paper so that the filtrate was obtained. The filter of filtrate was then evaporated using Rotary Evaporator at $50^{\circ} \mathrm{C}$ during 1 hour (depending on the amount of filtrate and solvent used) to evaporate ethanol until a thick extract was obtained. If the result of the Rotary Evaporator has not been thick or unlike the paste, then it could be continued by a water bath to produce a thick extract during 1 hour. The extract result obtained in the form of pasta as much as 15 gram. The pasta extract can be stored into the refrigerator with a temperature of $4^{\circ} \mathrm{C}$ till the extract will be applied later.

\section{Thin Layer Chromatography Test (TLC)}

The TLC test was performed to identify the active compounds contained in the ethanol extract of getih-getihan leaves (Rivina humilis L.). The active compounds tested by TLC include alkaloids, flavonoids, tannins and terpenoids.

a. TLC Test of Alkaloid Compounds Leaves extract of getihgetihan (Rivina humilis L.) was weighed as much as 0.1 gram. The extract was added $2 \mathrm{ml}$ of $2 \mathrm{~N} \mathrm{HCl}$. The mixture was heated over a water bowl for 2-3 minutes with stirring. When it was cold, added 0.1 gram of $\mathrm{NaCl}$, stirred until blended and filtered. The filtrate obtained then was added $2 \mathrm{ml}$ of $2 \mathrm{~N}$ $\mathrm{HCl}$ and ammonia until the solution became alkaline and let it for 15 minutes. The process was further extracted with $5 \mathrm{ml}$ of water-free chloroform and filtered. The resulting filtrate was evaporated to dryness, then dissolved in methanol. The solution was bottled on a TLC plate (Klesel gel 60 F254) using a capillary pipe. The bottled TLC plates were dissolved in ethyl acetate, methanol, and water phases with a ratio of 9: 2: 2 . The TLC plates were continued by spraying Dragendorf reagents. It was then observed to see if there is an orange colour appears then the extract contains alkaloids.

b. TLC Test of Flavonoid Compounds

The extract was weighed as much as 0.1 gram, then $1 \mathrm{ml}$ of $\mathrm{n}$ hexane was added repeatedly until the extract was colourless. The residue is dissolved in ethanol. The solution was bottled on the TLC plate (Klesel gel 60 F254). The bottled TLC plates were dissolved in the butanol, acetic, and water phases of motion with a ratio of 4 : 1: 5. TLC plates were given ammonia vapour impurities. If yellow intensive stain appears, the extract contains flavonoids.

c. TLC Test of Tannin Compound

The extract was weighed as much as 0.1 gram, added $3 \mathrm{ml}$ of hot water, stirred until evenly 
distributed and allowed to close to room temperature. The solution was added 2 drops $10 \% \mathrm{NaCl}$, then stirred until evenly distributed and filtered. The resulting filtrate was bottled using a capillary pipe on the TLC plate (Klesel gel 60 F254). The TLC plates were dissolved in chloroform and ethyl acetate eluates at a ratio of 1: 9. The removed TLC plates were sprayed with $\mathrm{FeCl} 3$ reagents. If there were changes in black colour, the extract contains tannin.

d. TLC Test of Terpenoid Compound The extract was weighed as much as $0.1 \mathrm{~g}$, plus some ethanol and stirred until dissolved. The solution was bottled with a capillary pipe on the TLC plate (Klesel gel 60 F254). The TLC plates were expelled in the mobile phase of nhexane and ethyl acetate with a ratio of 4: 1. TLC plates were sprayed with sulfuric acid anisaldehyde reagent stains. The extract contains terpenoid when the change is purplish or purple.

\section{Treatment Test Extract of Getih-getihan leaves on armyworm Mortality}

Prepared animals to be tested were armyworms (Spodoptera litura F.) instar phase III. Armyworm (Spodoptera litura F. were placed in 10 bottles per bottle. Each bottle consisted of a armyworm at the same instar, the length and weight of the armyworm relatively the same. Serial concentration of getih-getihan leaves extract (Rivina humilis L.) to be used was $0.5 \%, 1 \%, 1.5 \%, 2 \%, 2.5 \%$ and $0 \%$ as control (distilled). Fresh Ipomoea aquatica leaves were weighed as much as 5 grams for each bottle. Then the leaves of Ipomoea aquatica and armyworm were sprayed with leaves extract of getih-getihan (Rivina humilis L.) with serial concentration that has been determined. After that, the Ipomoea aquatica leaves were dried for 5 minutes. The Ipomoea aquatica leaves and armyworm has been sprayed into the bottle. The bottle was covered with a chiffon fabric and tied with a rubber band. Each bottle was labelled according to the treatment tested. Then, it is observed the mortality of armyworm (Spodoptera litura F.) every 24 hours once for 2 days or $2 \times 24$ hours.

\section{Data Analysis}

Data analysis to know the value of LC50 is probit analysis. The test performed was ANOVA test with 95\% confidence degree $(p<0.05)$, and continued with Duncan test to know the differences between treatments with a $95 \%$ confidence degree $(\mathrm{p}<0.05)$.

\section{RESULT}

The extract test result of getih-getihan leaves (Rivina humilis L.) to the mortality of the armyworm was analyzed probit Lethal Concentration (LC50), Anova test analysis, and followed by Duncan Test, as well as TLC Test results active compounds contained in the leaf extract of getih-getihan are as follows.

\section{The Lethal Concentration (LC50) Value of Extract of getih-getihan Leaves (Rivina humilis L.)}

Table 1. LC50 values upper limit and lower limit of concentration within of 48 hours.

\begin{tabular}{ccc}
\hline LC50 & $\begin{array}{r}\text { Upper } \\
\text { Limit }\end{array}$ & $\begin{array}{c}\text { Lower } \\
\text { Limit }\end{array}$ \\
\hline $1.42 \%$ & $1.55 \%$ & $1.29 \%$ \\
\hline
\end{tabular}

Based on Table 1. it can be seen that the LC50 leaves extract of getih-getihan (Rivina humilis L.) in span of 48 hours is at concentration $1.42 \%$, with the upper limit of $1.55 \%$ and the lower limit of $1.29 \%$.

\section{The effect of Getih-getihan leaves extract (Rivina humilis L.) on armyworm (Spodoptera litura F.)}


The observation result of getihgetihan leaves extract test to mortality of armyworm can be seen in Figure 1.

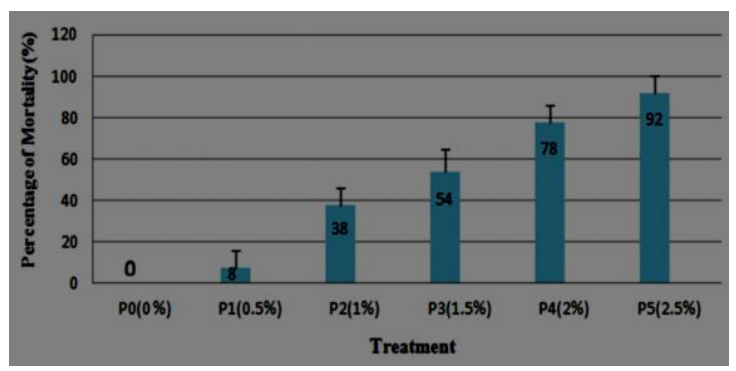

Figure 1. Average mortality rate histogram of Spodoptera litura F. on the treatment of getih-getihan leaves extract (Rivina humilis L.) within of 48 hours.

Figure 1 shows the percentage mortality of armyworm (Spodoptera litura F.) control treatment (P0), which uses aquadest, so the percentage of mortality is $0 \%$. The concentration of $0.5 \%$ (P1) $8 \%$ concentration, $1 \%$ concentration (P2) was $38 \%$, concentration of $1.5 \%$ (P3) was $54 \%$, concentration $2 \%(\mathrm{P} 4)$ of $78 \%$, and $2.5 \%$ concentration (P5) was $92 \%$. The results of the data obtained were analyzed and obtained differences between treatments tested by Duncan Test in Table 2 .

Table 2. Mortality of armyworm (Spodoptera litura F.) in the treatment Getih-getihan leaves extract (Rivina humilis L.) and the recapitulation of Duncan Test results.

\begin{tabular}{lc}
\hline $\begin{array}{c}\text { Treatm } \\
\text { ent }\end{array}$ & Average of Mortality \pm SD \\
\hline $\begin{array}{l}\text { P0 } \\
\text { (control) }\end{array}$ & $0.0 \pm 0.000^{\mathrm{a}}$ \\
P1 & $8.0 \pm 0.837^{\mathrm{a}}$ \\
$(0.5 \%)$ & $38.0 \pm 0.837^{\mathrm{b}}$ \\
P2 $(1 \%)$ & $54.0 \pm 1.140^{\mathrm{c}}$ \\
P3 & \\
$(1.5 \%)$ & $78.0 \pm 0.837^{\mathrm{d}}$ \\
P4 (2\%) & $92.0 \pm 0.837^{\mathrm{e}}$ \\
P5 & \\
$(2.5 \%)$ & \\
\hline
\end{tabular}

Note: The average followed by the same letter in the same column showed no significant difference in Duncan Test with 5\% significance level.

Table 2. shows the mean mortality of armyworm (Spodoptera litura F.) at P0 (control treatment) differs significantly from P2, P3, P4, and P5, but P1 differed not significantly with P0 (control treatment). Value effect on each treatment of getih-getihan Leaves extract (Rivina humilis L.) on the armyworm mortality (Spodoptera litura F.) was obtained with a $95 \%$ confidence degree $(\mathrm{p}<0.05)$. The effect of Getih-getihan leaves extract on armyworm mortality Was caused by the presence of active compounds contained in the extract. Identifying the extracted content can be known by means of TLC Test. The TLC test results of getih-getihan leaves extract is shown in Table 3 .

Table 3. TLC Test Results of getih-getihan leaves extract (Rivina humilis L.)

\begin{tabular}{llc}
\hline $\begin{array}{c}\text { Active } \\
\text { compounds }\end{array}$ & $\begin{array}{c}\text { Result } \\
\text { (Color) }\end{array}$ & Note $(+/-)$ \\
\hline Alkaloid & Orange & + \\
Flavonoid & Yellow & + \\
Tanin & Black & + \\
Terpenoid & Purple & + \\
\hline
\end{tabular}

Note: (+): available and (-):unavailable

\section{DISCUSSION}

The observation result and probit analysis showed that the concentration of $1.42 \%$ of the getih-getihan leaves extract could kill $50 \%$ of the animal population (armyworm). The serum concentration of the getih-getihan leaves extracts consisted of 5 treatments and 1 control. In the control treatment of P0 (0\%) using aquadest resulted in a percentage mortality of armyworm by $0 \%$. The control treatment was performed to test the armyworm with no toxic compounds contained in the extract, so that at the time of observation, it can be used as a comparison. The results showed that the greater the concentration of 
extract given, the more increased percentage mortality of armyworm. The greater the concentration is given, the more active compounds which are toxic to kill the armyworm.

Some identified active compounds by TLC test on getih-getihan leaves extracts include alkaloids, flavonoids, tannins, and terpenoids. If the active compounds come into the body of the armyworm, it can kill the armyworm. The active compound can enter and seep into the body of the armyworm in 2 ways through the feed which has been sprayed with the extract and through the cuticle layer on the parts of the armyworm body. Various active compounds have more than 1 mode of action such as alkaloids, flavonoids, and tannins.

Alkaloids, flavonoids, tannins, and terpenoids have a bitter taste, so it can resist eating (antifidan) and inhibit the activity of eating. Alkaloids can degrade cell membranes to enter and damage cells [20]. Alkaloids can also disrupt the nervous system, because it can inhibit the action of enzyme acetylcholinesterase which causes the disruption of skeletal muscle working into convulsions and getting paralyzed.[21].

Alkaloids also inhibit $\mathrm{Ca}^{2+}$ channels that cause heart muscle work disrupted. If the heart muscle can not move optimally, it can be ascertained that blood circulation in the armyworm will not be getting smooth and eventually die [20].

Flavonoids can cause the inhibition of the leucine amino acids required at the Krebs cycle stage [22] and inhibit the transport of electrons in the electron transport stage [23]. Delayed transport of electrons will also inhibit the cell respiration process to produce ATP or energy that is needed for the survival of armyworm.

Tannins are potentially becoming stomach poison because tannins cannot be digested by the stomach and have the binding power with proteins, carbohydrates, vitamins and minerals [22].
The nutritional needs of armyworm are less fulfilled due to tannin activity and affects the body's metabolic processes. Tannins may also decrease the activity of some digestive enzymes such as protease enzymes and amylases [20]. Enzyme is a macromolecule that acts as a catalyst, a chemical agent that speeds up the reaction without being consumed by reaction [24]. The enzyme is essential for breaking edible food into a simpler form, in order to facilitate the process of nutrient absorption required for the survival of armyworm. When the enzyme activity is inhibited, the process of body metabolism of armyworm cannot function. Food eaten by armyworm will be useless, so that the armyworm body is thinner than the armyworm sprayed by aquades.

Various ways in which active compounds are identified by the TLC test cause the Grayak caterpillar to die, it can be observed through the symptoms and compared them with the control treatment. Symptoms that are highly visible at the time of spraying occur at high concentrations such as concentrations of $2 \%$ and $2.5 \%$. Symptoms are initially very active movement when sprayed with extracts, then becomes slow until there is no movement. The symptoms correspond to the armyworm mortality due to contact toxins, excitation (exposed to stimulus), convulsions, paralysis and death [25]. Another change that is from the green colour with a white zig-zag line and black sphere along the body that was originally seen clearly, turned into a blackish brown on some parts of his body to almost all parts of his body. The body of armyworm is seen stretching or more elongated compared to the control treatment, on the legs looking stiff upwards, slightly flabby after a day then drying out, and smelly. Eating activity decreased, this is evidenced by the higher concentration of extract given, the more residual feed that is not eaten.

Various active compounds that have been identified by the TLC Test together with the potential work to kill the 
armyworm, allowing another active compound contained in the extract and the role of killing armyworm. In this study, there are obstacles to identify the active compound completely because no exact phase of motion has been found and no optimal separation has been obtained, and there are other constraints. Thus, it is necessary to conduct further research about the active compounds contained in the leaves of getih-getihan, the utilization of getih-getihan plants in the field of agriculture and other fields.

\section{CONCLUSION}

Various active compounds contribute to killing armyworm. The various active compounds identified by TLC on the getihgetihan leaves extract are alkaloids, flavonoids, tannins, and terpenoids. The value of Lethal Concentration (LC50) of getih-getihan leaves extract (Rivina humilis L.) to armyworm mortality (Spodoptera litura F.) was $1.415 \%$. The value of LC50 is to determine the toxicity of the extract as a vegetable pesticide. Getih-getihan leaves extract (Rivina humilis L.) had a very significant effect on armyworm mortality (Spodoptera litura F.) $(\mathrm{p}=0,000)$.

\section{REFERENCES}

[1] Sari, M., Lubis, L., Pangestiningsih, Y. 2013. Uji Efektivitas Beberapa Insektisida Nabati untuk Mengendalikan Ulat Grayak (Spodoptera Litura F.) (Lepidoptera: Noctuidae) di Laboratorium. Jurnal Online Agroekoteknologi. Vol. 1 (3): 560-569.

[2] Islam, T., Das, G., Ali, M. 2015. Efficacy of Lufenuron, A Chitin Synthesis Inhibitor on The Mortality of Spodoptera Litura (Fabricius) Under Laboratory Conditions. Journal of Entomology and Zoology Studies. Vol. 3 (3): 480-483.
[3] Tarigan, R., Tarigan, M.U., Oemry, S. 2012. Uji Efektifitas Larutan Kulit Jeruk Manis dan Larutan Daun Nimba untuk Mengendalikan Spodoptera Litura F. (Lepidoptera: Noctuidae) pada Tanaman Sawi Di Lapangan. Jurnal Online Agroekoteknologi. Vol. 1 (1): 172-182.

[4] Petrus \& Parawansa I. N. R. 2014. Efektivitas Ekstrak Daun Kembang Bulan (Tithonia diversifolia) terhadap Pengendalian Hama Ulat Plutella Xylostella pada Tanaman Sawi. Jurnal Agrisistem. Vol. 10 (2): 162-169.

[5] Sudarmo, S. dan Mulyaningsih S. 2014. Mudah Membuat Pestisida Nabati Ampuh. Jakarta: PT Agro Media Pustaka.

[6] Hendrival, Latifah, Nisa, A. 2013. Efikasi Beberapa Insektisida Nabati Untuk Mengendalikan Hama Pengisap Polong di Pertanaman Kedelai. Jurnal Agrista. Vol. 17 (1): 18-27.

[7] Kardinan, A. 2001. Pestisida Nabati Ramuan dan Aplikasi. Jakarta: PT. Penebar Swadaya.

[8] Nurhidayati, Pujiwati, I., Solichah A., Djuhari, Basit, A., E. 2008. Book Pertanian Organik Suatu Kajian Sistem Pertanian Terpadu dan Berkelanjutan. Jurusan Budidaya Pertanian, Fakultas Pertanian. Malang: Universitas Islam Malang.

[9] Jeyasankar, A., Chinnamani, T. 2014. Bioactivity of Pseudocalymma alliaceum (Lam.) Sandwith (Bignoniaceae) against Spodoptera litura Fabricius and Helicoverpa armigera Hubner (Lepidoptera: Noctuidae). Journal of Coastal life Medical. Vol. 2 (4): 302307. 
[10] Abrori, M. 2016. Keanekaragaman Tumbuhan Bawah Di Cagar Alam Manggis Gadungan Kecamatan Puncu Kabupaten Kediri. Skripsi. Jurusan Biologi, Fakultas Sains dan Teknologi. Malang: Universitas Islam Negeri.

[11] Wilson, E.O. 2012. State of Biodiversity Report: 2011/2012. South Africa: Environmental Planning and Climate Protection Departement.

[12] Nelson, L.S., Shih, R.D., Balick, M.J. 2007. Handbook of Poisonous and Injurious Plants. New York: Springer.

[13] Adeyemi, M.M. \& Mohammed, M. 2012. Prospect of Antifeedant Secondary Metabolites as Post Harvest Material. International Journal of Innovative Research in Science. Vol. 3 (1): 8701-8708.

[14] Joseph, E. \& Elvita S.R. 2013. Phytochemical Screening and Bioactivity Assay of Selected South Indian Phytolaccaceae. Journal of Nature and Life Science. Vol. 1 (1): 26-30.

[15] Fathima, M. \& Tilton, F. 2012. Phytochemical Analysis and Antioxidant Activity of Leaf Extracts of Rivina humilis L. International Journal of Current Research. Vol. 4 (11): 326-330.

[16] Elumalai, A., Krishnappa, K., Kalaichelvi, N., Elumalai, K. 2015. Insecticidal, ovicidal and repellent activities of different solvent extracts of Rivina humilis Linn. (Phytolaccaceae) against the selected stored grain pest, Tribolium castaneum Herbs. (Coleoptera : Tenebrionidae). International Journal of Advanced Research in Biological Sciences. Vol. 2 (10): 161-169.

[17] Vargas, R.A., Malacara, C.E., Petricevich, V.I. 2016. Characterization of Chemical Compounds with Antioxidant and Cytotoxic Activities in
Bougenvillea $x$ buttiana Holttum and Standl, (var. Rose) Extracts. Article antioxidants. Vol. 5 (45): 1-11.

[18] Azis, T., Febrizky, S., Mario, A. D. 2014. Pengaruh Jenis Pelarut terhadap Persen Yield Alkaloid dari Daun Salam India (Murraya Koenigii). Jurnal Teknik Kimia. Vol. 20 (2): 1-6.

[19] Bandar, H., Hijazi, A., Rammal, H., Hachem, A., Saad, Z., Badran, B. 2013. Techniques for the Extraction of Bioactive Compounds from Lebanese Urtica dioica. American Journal of Phytomedicine and Clinical Therapeutics. AJPCT (1) (6): 507-5013.

[20] Gokok, S. 2017. Uji Toksisitas Bioinsektisida Ekstrak Metanol Buah Bintaro (Cerbera odollam L.) terhadap Mortalitas Ulat Grayak (Spodoptera litura) pada Pakan Daun Tomat. Skripsi. Program Studi Pendidikan Biologi, Jurusan Pendidika MIPA, FKIP. Yogyakarta: Universitas Sanata Dharma.

[21] Kaihena, M., Lalihatu, V., Nindatu, M. 2012. Efektivitas Ekstrak Etanol Daun Sirih (Piper betle L.) terhadap Mortalitas Larva Nyamuk Anopheles sp. dan Culex. Jurnal Kedokteran dan Kesehatan. Vol. 4 (1): 88-105.

[22] Permana, R.E., Moerfiah, Triastinurmiatiningsih. 2016. Pemanfaatan Ekstrak Daun Karuk (Piper sarmentosum) sebagai Insektisida Nabati Hama Ulat Grayak (Spodoptera litura). Vol. (1): 1-12.

[23] Sumampouw, S.P., Pijoh, V.D., Wahongan, G.J. 2014. Pengaruh Larutan Bawang Putih (Allium sativum) pada Larva Aedes spp Di Kecamatan Malalayang Kota Manado. Jurnal eBiomedik (eBM). Vol. 2 (2): 1-6. 
[24] Campbell, N.A., Reece J.B., Urry, L.A., Cain, M.I, Wasserman, S.A., Minorsky, P.V., Jackson R.B. 2008. Biology Eigth Edition. San Francisco: Benjamin Cammings.
[25] Maharani, S. 2016. Uji Toksisitas Fraksi Metanol dan N-Heksan Ekstrak Daun Bintaro (Cerbera Odollam G.) terhadap Mortalitas Ulat Grayak (Spodotera litura F.) dan Pemanfaatannya sebagai Buku Ilmiah Populer. Skripsi. Jember: Universitas Jember 